\title{
IMPLEMENTASI PENGEMBANGAN KOTA LAYAK ANAK DI KOTA SUKABUMI
}

\author{
Ceria Cantika Maulida ${ }^{1}$ \& Dian Purwanti ${ }^{2}$ \\ ${ }^{1}$ Universitas Muhammadiyah Kota Sukabumi \\ Email: ceriacantika_m@yahoo.com \\ ${ }^{2}$ Universitas Padjajaran Bandung \\ Email: purwantidian75@yahoo.com
}

\begin{abstract}
Abstrak
Penelitian ini bertujuan untuk mengetahui implementasi pengembangan kota layak anak di Kota Sukabumi menggunakan teori Van Meter dan Van Horn. Metode yang digunakan dalam penelitian ini adalah metode kualitatif deskripfif dengan pengumpulan data melalui teknik wawancara, observasi, dan dokumentasi. Analisis data yang digunakan dengan menggunakan model Milles dan Huberman. Hasil penelitian menunjukan bahwa implementasi kebijakan pengembangan kota layak anak di Kota Sukabumi sudah dilaksanakan cukup baik karena sudah adanya inisiatif pemerintah Kota Sukabumi dalam mendukung adanya kebijakan ini melalui kegiatan, dan pembentukan gugus tugas untuk mempermudah lancarnya implementasi. Meskipun dalam pelaksanaannya kebijakan ini belum dilakukan secara optimal karena kurangnya sumber daya, dan kurangnya sosialisasi yang dilakukan kepada masyarakat. Saran yang dapat diberikan yaitu diharapkan dapat meningkatkan fasilitas dalam pemenuhan hak anak baik itu sumber daya manusia maupun sumber daya finansial, dan pemerataan sosialisasi yang dilakukan terhadap masyarakat.
\end{abstract}

Kata Kunci: Implementasi Kebijakan, Kota Layak Anak, Kota Sukabumi.

\begin{abstract}
This study aims to determine the implementation of child-friendly city development in the City of Sukabumi using the Van Meter and Van Horn theory. The method used in this research is descriptive qualitative method by collecting data through interview, observation, and documentation techniques. Analysis of the data used by using Milles and Huberman models. The results showed that the implementation of child-friendly city development policies in Sukabumi City had been carried out quite well because of the Sukabumi City Government's initiative in supporting this policy through activities, and the formation of a task force to facilitate smooth implementation. Although in its implementation this policy has not been carried out optimally due to lack of resources, and lack of socialization carried out to the public. Suggestions that can be given are expected to be able to improve facilities in the fulfillment of children's rights both human and financial resources, and equitable dissemination of information dissemination to the community.
\end{abstract}

Keywords: Policy Implementation, Child Friendly City, Sukabumi City. 


\section{A. PENDAHULUAN}

Dalam Undang-Undang Perlindungan Anak dikatakan bahwa "anak adalah seorang yang belum berusia 18 (delapan belas) tahun, termasuk anak dalam kandungan”. Oleh karena itu bibit tunas bangsa ini harus mendapatkan prioritas yang utama dalam pembangunan. Dan tumbuh kembang anak harus diimbangi dengan adanya pemenuhan hak anak yang sesuai. Namun kenyataanya anak seringkali mendapatkan perlakukan yang salah.

Sebagai upaya untuk memberikan perlindungan anak, pemerintah membuat suatu kebijakan pengembangan Kota Layak Anak atau KLA. Menurut Anderson (Tahir, 2015) "kebijakan adalah suatu tindakan yang dilakukan seseorang pelaku atau sejumlah pelaku yang memecahkan suatu masalah". Selanjutnya Anderson mengklasifikasi kebijakan menjadi dua, yaitu subtantif dan prosedural. Kebijakan subtantif yaitu apa yang harus dikerjakan oleh pemerintah sedangkan kebijakan prosedural yaitu siapa dan bagaimana kebijakan tersebut diselenggarakan. Ini berarti kebijakan publik adalah kebaikan kebaikan yang dikembangkan oleh badan-badan dan pejabat-pejabat pemerintah.

Kebijakan ini merupakan kebijakan yang dicanangkan oleh pemerintah pusat dengan payung hukumnya peraturan menteri pemberdayaan perempuan dan perlindungan anak Nomor 11 Tahun 2011 Tentang Kebijakan Pengembangan KLA. KLA merupakan sistem pembangunan Kota Layak Anak yang mengintegrasikan komitmen dan sumberdaya pemerintah, masyarakat, dunia usaha yang terencana secara menyeluruh dan berkelanjutan dalam kebijakan, program dan kegiatan untuk pemenuhan hak-hak anak. Adanya kebijakan ini merupakan salah satu bentuk ratifikasi dari konvensi hak anak dalam mewujudkan dan memenuhi hak anak yang tercantum dalam Undang-Undang No. 35 Tahun 2014 tentang perlindungan anak. Untuk itu kebijakan KLA terus menerus disosialisasikan untuk meminimalisir adanya pelanggaran terhadap hak anak. Selain itu adanya kebijakan KLA ini juga untuk memenuhi kebutuhan maupun mengedapankan kepentingan anak.

Kebijakan KLA ini kemudian diimplementasikan di Kota Sukabumi. Menurut dinas Kependudukan dan Pencatatan Sipil Kota Sukabumi terdapat 105.675 anak yang tersebar di wilayah kecamatan Kota Sukabumi. Keberadaan anak di Kota Sukabumi menjadi faktor mengapa kesejahteraan anak harus menjadi prioritas yang utama. Oleh karena itu pemerintah Kota Sukabumi berkewajiban mengintegrasikan kebijakan daerah dengan kebijakan yang ada di pusat dalam upaya menjadikan Indonesia sebagai "IDOLA" atau disebut sebagai Indonesia Layak Anak dengan mengimplementasikan KLA. 
Dalam pengembangan KLA terbagi menjadi beberapa klaster sebagai indikator yang memudahkan klasifikasi pemenuhan anak yang harus dimiliki oleh setiap daerah untuk mendapatkan predikat KLA. Adapun Klaster tersebut dibagi menjadi:

1. Klaster 1: Hak Sipil dan Kebebasan

2. Klaster 2: Likungan Keluarga dan Pengasuhan Alternatif

3. Klaster 3: Kesehatan Dasar dan Kesejahteraan

4. Klaster 4: Pendidikan, Pemanfaatan Waktu Luang \& Kegiatan Budaya

5. Klaster 5: Perlindungan Khusus

Meskipun pengembangan KLA di Kota Sukabumi telah dijalankan dan pada beberapa kluster pemenuhan hak anak telah dikatakan baik namun masih ada permasalahan yang menghambat Kota Sukabumi menjadi kota yang layak anak. Salah satunya adalah permasalahan pada kluster perlindungan khusus karena masih tingginya angka permasalahan pada anak. Hal ini bisa dilihat dalam data grafik berikut:

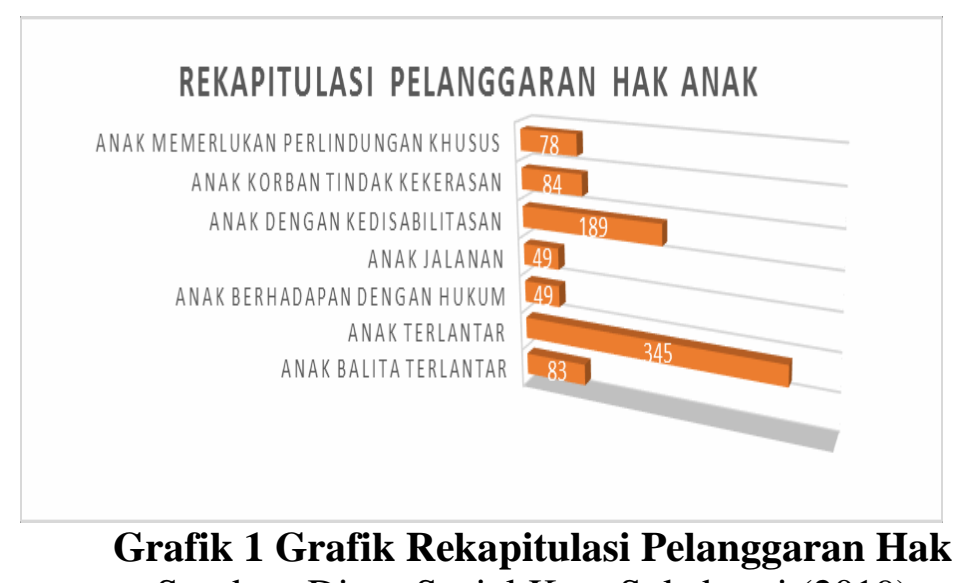

Sumber: Dinas Sosial Kota Sukabumi (2019)

Pada tahun 2018 menurut Dinas Sosial terdata ada 83 anak balita terlantar, 345 anak terlantar, 49 anak berhadapan dengan hukum, 49 anak jalanan, 189 anak dengan kedisabilitasan (ADK), kemudian 84 anak yang menjadi korban tindak kekerasan dan 78 anak yang memerlukan perlindungan secara khusus.

Selain tingkat permasalahan anak yang masih tinggi, Kota Sukabumi masih kekurangan fasilitas pendukung dalam penanganan permasalahan anak, salah satunya adalah kurangnya fasilitas rehabilitas bagi anak dan belum terbentuknya forum anak perwilayah secara keseluruhan. Di Kota Sukabumi sendiri baru ada 2 forum anak yang dibentuk perwilayah, yaitu wilayah kecamatan Citamiang, dan kecamatan Cikole.

Berdasarkan observasi awal yang peneliti lakukan, peneliti menemukan fenomena masalah sebagai berikut: 
1. Ukuran dan Tujuan Kebijakan

Ukuran dan Tujuannya dibuat kebijakan KLA ini masih belum tercapai karena masih tingginya permasalahan anak pada kluster perlindungan khusus. Hal ini menyebabkan Kota Sukabumi belum dikatakan sebagai kota yang layak anak.

2. Sumberdaya

Sumber daya belum mencukupi pada kluster perlindungan khusus di dinas sosial. Karena saat ini dinas sosial belum memiliki tenaga profesional dalam penanganan kasus anak yaitu tidak adanya seorang ahli psikologi sehingga apabila terjadi permasalahan pada anak hanya dibantu oleh pekerja sosial (peksos), namun saat ini dinas sosial hanya memiliki 1 orang pekerja sosial. Kemudian fasilitas dalam menunjang kebijakan ini masih kurang, karena Kota Sukabumi belum memiliki tempat rehabilitas bagi anak.

3. Komunikasi

Komunikasi yang belum optimal. Hal ini dapat dilihat dari ketidaktahuan masyarakat terkait adanya kebijakan KLA dan kurangnya informasi masyarakat mengenai adanya lembaga penyediaan layanan konsultasi kesejahteraan keluarga (LK3) dan P2TP2A di Kota Sukabumi karena kurangnya sosialisasi yang dilakukan. Selain itu keberadaan forum anak daerah juga belum banyak diketahui oleh masyarakat dan juga anak. kemudian dalam pengimplementasian kebijakan ini, koordinasi yang dilakukan oleh dinas Pengendalian Penduduk, KB, P3A,dan Pemberdayaan Masyarakat dalam penguatan komitmen pemenuhan hak anak hanya dilakukan setiap 2 kali dalam satu tahun sehingga kurangnya monitoring yang berkelanjutan.

4. Karakteristik agen pelaksana.

Sejauh ini dalam mengimplementasikan kebijkan KLA oleh dinas Dalduk, KB, P3A dan Pemberdayaan Masyarakat yang sebagai leading sektor dalam kebijakan ini, telah melakukan kebijakan ini sesuai dengan SOP atau Standar Operasional Procedure. Selain itu dukungan dapat dilihat dengan adanya program dan kegiatan sesuai dengan kluster nya masing-masing. Namun implementor dalam kluster pada perlindungan khusus masih belum menjalankan kebijakan ini dengan efektif karena adanya keterbatasan yang dimiliki dalam segi fasilitas.

5. Lingkungan ekonomi, sosial, dan politik. 
Dalam faktor ini, lingkungan politik sudah mendukung adanya kebijakan pengembangan KLA, yaitu dengan dibuatnya Peraturan Daerah Nomor 4 Tahun 2013 mengenai perlindungan anak yang didalamnya mencangkup kebijakan KLA, selain itu dukungan politik juga dapat dilihat dari inisiatif pemerintah dalam pembentukan kepengurusan gugus tugas KLA untuk memudahkan koordinasi yang terjalin. Namun jika dilihat dari faktor sosial dan ekonomi, dukungan masyarakat masih kurang, hal ini dikarenakan mayarakat belum mengetahui adanya kebijakan KLA ini.

6. Sikap para pelaksana (disposisi)

Keterlibatan agen pelaksana dalam pengembangan KLA sebagian besar sudah mendukung, hal ini dapat dilihat dengan adanya sebagian kegiatan, program yang menunjang dalam pemenuhan hak anak pada setiap kluster KLA yang salah satu diantaranya adalah sekolah ramah anak, puskesmas ramah anak, penyedian lembaga kesejahteraan sosial anak. Namun agen pelaksana dalam kluster perlidungan khusus memang belum melaksanakan pemenuhan hak anak pada penyedian fasilitas yang layak untuk anak, hal ini dikarenakan adanya perbedaan prioritas dalam pemenuhan hak anak pada setiap dinas yang terkait dengan klaster perlindungan khusus.

Penelitian ini bertujuan untuk mengetahui implementasi kebijakan pengembangan kota layak anak di Kota Sukabumi, serta faktor pendukung dan penghambat dalam implementasi kebijakan pengembangan kota layak anak di Kota Sukabumi

\section{B. KAJIAN PUSTAKA}

\section{Konsep Kebijakan Publik}

Istilah kebijakan (policy) seringkali penggunaannya dipertukarkan dengan istilahistilah lain seperti tujuan (goals), program, keputusan, undang-undang, ketentuan- ketentuan, usulan-usulan dari rancangan besar. Menurut Titmuss (Suharto, 2014) kebijakan dijelaskan sebagai prinsip-prinsip yang mengatur tindakan yang diarahkan kepada tujuan-tujuan tertentu. Mustopadidjaja (Tahir, 2015) mengatakan bahwa istilah kebijakan lazim digunakan dalam kaitannya atau kegiatan pemerintah, serta perilaku negara pada umumnya dan kebijakan tersebut dituangkan dalam beberapa bentuk peraturan. Hal ini serupa dengan apa yang dikatakan Easton (Tahir, 2015) mendifiniskan bahwa kebijakan pemerintah sebagai alokasi otoritatif bagi seluruh masyarakat sehingga semua yang dipilih pemerintah untuk dikerjakan atau tidak dikerjakan adalah hasil alokasi nilai-nilai tersebut. 
Selanjutnya menurut Dye mengemukakan bahwa kebijakan publik adalah apapun yang dipilih pemerintah untuk dilakukan atau tidak dilakukan (Pasalong, 2013). Menurutnya bahwa apabila pemerintah memilih untuk melakukan sesuatu maka harus ada tujuan dan kebijakan negara tersebut harus meliputi semua tindakan pemerintah, bukan semata-mata pernyataan pemerintah atau pejabatnya. Disamping itu sesuatu yang yang tidak dilaksanakan oleh pemerintah pun termasuk kebijakan negara. Ciri-ciri khusus yang melekat pada kebijakan-kebijakan publik bersumber pada kenyataan bahwa kebijakan itu lazimnya dipikirkan, didesain, dirumuskan, dan diputuskan oleh mereka yang oleh Easton disebut sebagai orang-orang yang memiliki otoritas dalam sistem politik (Wahab, 2017).

Studi implementasi dalam Agustino (2014), merupakan suatu kajian mengenai kebijakan yang mengarah pada proses pelaksanaan dari suatu kebijakan. Implementasi dipandang secara luas mempunyai makna pelaksanaan undang-undang dimana berbagai aktor, organisasi, prosedur, dan teknik bekerja bersama-sama untuk menjalankan kebijakan dalam upaya untuk meraih tujuan-tujuan kebijakan atau program-program (Winarno, 2014). Implementasi kebijakan pada prinsipnya adalah cara agar sebuah kebijakan dapat mencapai tujuannya. Untuk mengimplementasikan kebijakan publik maka ada dua pilihan langkah yang ada, yaitu langsung mengimplementasikan dalam bentuk program atau melalui formulasi kebijakan derivat atau turunan dari kebijakan publik tersebut.

\section{Model Implementasi Kebijakan Publik}

Van Meter dan Van Horn mengembangkan model yang yang disebut sebagai a model of policy implementation process (model proses implementasi kebijakan) (Mutiarin \& Arif, 2014). Model ini menganggap bahwa implementasi kebijakan dipengaruhi oleh dimensi kebijakan, yaitu umlah masing-masing perubahan yang dihasilkan dan Jangkauan/lingkup kesepakatan terhadap tujuan antara pihak-pihak yang terlibat dalam proses implementasi akan lebih tinggi jika perubahan yang dihendaki relatif sedikit, sementara kesepakatan terhadap tujuan terutama dari mereka yang mengoperasikan program dilapangan relatif tinggi.

Hal lain yang dikemukakan Van Meter dan Van Horn adalah bahwa jalan yang menghubungkan antara kebijakan dan prestasi kerja dipisahkan oleh sejumlah variabel bebas yang saling berkaitan yaitu:

a. Ukuran dan tujuan kebijakan

b. Sumber-sumber kebijakan

c. Karakteristik agen pelaksana 
d. Komunikasi antar organisasi terkait dengan kegiatan-kegiatan pelaksanaan.

e. Sikap para pelaksana

f. Lingkungan ekonomi, sosial, dan politik.

Menurut Van Meter dan Van Horn ada lima variabel yang mempengaruhi kinerja implementasi, yakni (1) Standar dan sasaran kebijakan; (2) sumberdaya; (3) komunikasi antar organisasi dan penguatan aktivitas; (4) karakteristik agen pelaksan; (5) kondisi sosial, ekonomi dan politik.

Standar sasaran kebijakan harus jelas dan terukur sehingga dapat direalisasikan dengan mudah. Apabila standar dan sasaran kebijakan kabur, maka akan terjadi multiinterpretasi dan mudah menimbulkan konflik diantara para agen pelaksana implementasi. Disamping itu sumber daya harus mencukupi. Implementasi kebijakan perlu didukung sumberdaya manusia, maupun sumber daya non manusia.

Selanjutnya faktor hubungan antar organisasi. Dalam banyak program implementassi sebuah program perlu dukungan dan koordinasi dan kerjasama antar instansi bagi keberhasilan suatu program. Berikutnya adalah faktor karakteristik agen pelaksana, yang dimaksud karakteristik agen pelaksana adalah mencangkup struktur birokrasi, norma- norma dan pola-pola hubungan yang terjadi dalam birokrasi yang semua itu mempengaruhi implementasi suatu program. Faktor lainnya adalah kondisi sosial, politik dan ekonomi. Variabel ini mencangkup sumber daya ekonomi lingkungan yang dapat mendukung keberhasilan implementasi kebijakan; sejauh mana kelompok-kelompok kepentingan memberikan dukungan bagi implementasi kebijakan; karakteristik para partisipan yakni mendukung atau menolak; bagaimana sifat opini publik yang ada di lingkungan; dan apakah elite politik mendukung implementasi kebijakan.

Dan faktor terakhir adalah disposisi implementor. Disposisi implementor ini mencangkup tiga hal yang penting yakni:

a. Respon implementor terhadap kebijakan yang akan mempengaruhi kemaunnya untuk melaksanakan kebijakan

b. Kognisi, yakni pemahaman terhadap kebijakan;

c. Intensitas disposisi implementor, yaki preferensi nilai yang dimiliki oleh implementor.

\section{Definisi dan Tujuan KLA}

Dalam peraruran Menteri Negara Pemberdayaan Perempuan dan Perlindungan Anak No 11 Tahun 2011 tentang Kebijakan Pengembangan Kabupaten/Kota Layak Anak pada 
pasal 1 ayat 3 yang dimaksud dengan KLA adalah "Kabupaten/Kota Layak Anak merupakan sistem pembangunan Kabupaten/Kota yang mengintegrasikan komitmen dan sumberdaya pemerintah, masyarakat, dan dunia usaha yang yang terencana secara menyeluruh dan berkelanjutan dalam kebijakan, program, dan kegiatan untuk pemenuhan hak-hak anak."

Pentingnya mewujudkan KLA karena:

a. Jumlah anak sepertiga dari total penduduk

b. Anak merupakan modal dan investasi sumber daya manusia di masa yang akan datang sekaligus sebagai generasi penerus bangsa

c. Anak harus berkualitas agar tidak menjadi beban pembangunan

d. Koordinasi dan kemitraan antar pemangku kepentingan terkait pemenuhan hak anakhak anak harus dapat diperkuat agar terintegrasi, holistik, dan berkelanjutan.

Tujuan KLA ialah untuk membangun inisiatif pemerintah kabupaten/kota yang mengarah pada upaya transformasi Konvensi Hak-Hak anak (Convention on the right of the child) dari kerangka hukum kedalam definisi, strategi, dan intervensi pembangunan ke dalam bentuk kebijakan, program, dan kegiatan pembangunan yang ditujukan untuk pemenuhan hak-hak anak pada suatu wilayah kabupaten/kota.

\section{METODE PENELITIAN}

Penelitian ini menggunakan pendekatan kualitatif deskriptif yang menggunakan latar alamiah, dengan maksud menafsirkan fenomena yang terjadi dan dilakukan dengan jalan melibatkan berbagai metode yang ada (Satori \& Komariah, 2011). Penelitian ini menggunakan teknik pengumpulan data berupa wawancara, observasi, dan studi dokumentasi. Dalam penentuan informan peneliti menggunakan metode purposive sampling yang artinya informan dalam penelitian ini berdasarkan pertimbangan tertentu yang peneliti tentukan sendiri yang peneliti anggap informan yang telah ditentukan itu mengetahui informasi yang peneliti butuhkan.Sedangkan tahap validasi yang peneliti lakukan adalah dengan cara triangulasi sumber dan waktu. Adapun analisis yang digunakan menggunakan model Milles dan Huberman (Sugiyono, 2014).

\section{HASIL DAN PEMBAHASAN}

Deskripsi penelitian ini didasarkan pada konsep teori Van Meter dan Van Horn dengan enam dimensi. Dalam teori tersebut dijelaskan bahwa terdapat enam dimensi yaitu ukuran dan tujuan kebijakan, sumber-sumber kebijakan, komunikasi antar organisasi, 
karakteristik agen pelaksana, kondisi ekonomi dan politik dan kecenderungan pelaksana harus dilaksanakan dengan baik yaitu:

1. Ukuran dan Tujuan Kebijakan

Aspek yang dilihat dalam keberhasilan kebijakan ini yaitu dengan memenuhi 5 klaster dalam pemenuhan hak anak, selain itu aspek lainnya adalah dilihat dari sarana fasilitas, dan inftrastruktur dalam menunjang kegiatan anak yang ramah bagi anak. Namun yang terjadi dilapangan ukuran kebijakan ini belum tercapai, karena kurangnya pemenuhan hak anak pada kluster perlindungan khusus. Tujuan dari kebijakan pengembangan kota layak anak ini sendiri adalah untuk menjadikan Kota Sukabumi sebagai kota hunian yang layak dan ramah terhadap anak, selain itu tujuan dari kebijakan ini untuk meningkatkan inisiatif pemerintah untuk selalu menjadikan anak sebagai prioritas yang setiap hak nya perlu untuk dilindungi.

2. Sumber Daya

Sumber daya fasilitas yang dimiliki Kota Sukabumi memang belum semuanya terpenuhi, salah satunya keberadaan rumah singgah dalam menunjang pemenuhan hak anak di klaster perlindungan khusus. Selain itu sumber daya manusia pada leading sektor, dan gugus tugas P2TP2A dan dinas sosial masih dianggap kurang. Dari segi sumber daya finansial pun setiap gugus tugas memiliki kendala masing-masing, karena anggaran yang diberikan kecil. Dan dalam kebijakan ini memang belum ada pendanaan yang dikhususkan untuk kebijakan kota layak anak.

\section{Komunikasi Antar Organisasi}

Komunikasi semua pihak yang terkait dengan adanya kebijakan ini sudah dilakukan. Salah satu komunikasi yang dilakukan adalah dinas pengendalian penduduk, KB, P3A dan PM mensosialisasikan kegiatan kota layak anak dengan dilakukannya pertemuan koordinasi dengan semua pihak gugus tugas, dan semua pihak yang terkait dengan kebijakan ini dengan melakukan pertemuan rutin setiap satu tahun dua kali untuk membahas perencanaan dan evaluasi kegiatan yang diselenggaran oleh setiap instansi dalam pemenuhan hak anak, kemudian sosialisasi juga dilakukan oleh dinas dan lembaga yang memang kegiatnnya konsen terhadap anak, seperti halnya lembaga P2TP2A yang mensosialisikan keberadaan lembaga dan kegiatannya melaui famplet, banner, kegiatan pertemuan dengan 7 kecamatan, dan sosisalisai melalui radio. Hal ini juga dilakukan oleh forum anak yang juga mensosialisasikan kegiatannya melalui pemanfaatan media sosial yang ada. Meskipun sosialisasi sudah dilakukan terhadap masyarakat, komunikasi yang dilakukan belum 
dilakukan secara optimal karena masyarakat belum mengetahui adanya kebijakan kota layak anak.

4. Karakteristik Agen Pelaksana

Dalam dimensi karakteristik agen pelaksana, dinas pengendalian penduduk, KB, P3A dan PM sebenarnya sudah melakukan pelaksanaan kebijakan ini sesuai dengan SOP nya mulai dari mulai persiapan, hingga ke tahap evaluasi. Hal ini dibuktikan dengan diadakannya rapat atau pertemuan yang memang membahas pengengembangan kota layak anak dengan dikomunikasikan kepada setiap SKPD yang diundang. Kemudian karakteristik agen pelaksana lainnya telihat cukup baik ketika mengikuti kegiatan yang diselenggarakan oleh dinas pengendalian penduduk, KB, P3A dan PM, hanya saja dalam hal ini dinas sosial mengeluhkan karen merasa adanya over lap yang terjadi dilapangan. Sedangkan tanggapan masyarakat menggangap bahwa karakteristik agen pelaksana belum aktif dalam mensosialisasikan kepada masyarakat mengenai kebijakan ini, sehingga pemahaman masyarakat kurang dengan adanya kebijakan ini.

5. Kondisi Lingkungan, ekonomi dan Politik

Kebijakan pengembangan kota layak anak sebetulnya sudah didukung oleh pemerintah, dari segi kebijakan-kebijakan yang dibuat, dan penguatan komitmen gugus tugas, namun dalam pengadaan fasilitas yang menunjang pemenuhan hak anak, pemerintah belum mendukung secara penuh, mungkin dikarenakan karena keterbatasan anggaran, selain itu dukungan dunia usaha pun belum semua terlibat, sedangkan yang dirasakan oleh sebagian informan mengtakakan bahwa dukungan masyarakat itu masih kurang peduli, karena kebijakannya saja belum ditegakan. Hal ini serupa dengan penelitian sebelumnya, yang dirasakan bahwa masyarakat cenderung individualis, kurangnya kepedulian.

\section{Kecenderungan Agen Pelaksana}

Dukungan implementor sudah mendukung, dukungan ini dapat terlihat dari kegiatankegiatan yang diselenggrakan oleh pelaksananya sendiri, salah satunya forum anak yang memberikan dukungannya dengan membuat segala kegiatan, kemudian peran gugus tugas yang terkait kebijakan ini telah melakukan perannya sesuai dengan tupokasinya dalam penangan anak.

Dalam pelaksanaan implementasi kebijakan pengembanagan kota layak anak di Kota Sukabumi yang dilakukan oleh Dinas Pengendalian Penduduk, KB, P3A dan PM dilihat dari faktor internal yaitu adanya dukungan dari semua SKPD dalam pelaksanaan dan kegiatan yang menunjang pemenuhan hak anak, selain itu dibentuknya gugus tugas yang telah di SK 
kan walikota juga memberikan kemudahan untuk mengumpulkan data instrumen atau indikator yang diminta oleh kementrian pemberdayaan perempuan dan perlindungan anak, dengan adanya gugus tugas tersebut mempermudah komunikasi yang baik yang dilakukan oleh dinas pengendalian penduduk KB, P3A dan PM kepada seluruh orang yang terlibat dengan pengembangan kebijakan kota layak anak.

Dalam pengimplementasian pengembangan kebijakan kota layak anak yang dilakukan di Kota Sukabumi pada klaster perlindungan khusus, yaitu dengan kurangnya fasilitas yang dimiliki Kota Sukabumi, salah satunya pengadaan rumah singgah. Kemudian sumber daya manusia juga kurang memadai di leading sektor Dinas Pengendalian Penduduk, KB, P3A dan PM, selain itu kekurangan sumber daya manusia juga dirasakan oleh dinas sosial sebagai gugus tugas kota layak anak. bukan hanya itu sumber daya finansial pun menjadi faktor yang menghambat pengembangan kota layak anak, dikarenakan pendanaan APBD yang diberikan relatif kecil, sehingga dalam membuat kegiatan, memnuhi fasilitasn dan hal lainnya sulit diadakan karena kurangnya sumber daya finansial.

\section{E. KESIMPULAN}

Berdasarkan hasil penelitian diketahui bahwa kebijakan pengembangan kota layak di Kota Sukabumi belum sepenuhnya berjalan baik karena dalam pengimplementasia kebijakan ini masih adanya hambatan yang dirasakan oleh pemerintah Kota Sukabumi, walaupun pemerintah pada dasarnya sudah berupaya dalam mengimplementasian kebijakan ini dengan baik melalui kegiatan dan pembentukan kelembagaan gugus tugas. Hal ini karena kurangnya sumber daya manusia, finansial, sarana dan prasanan yang dimiliki, kemudian masyarakat juga tidak mengenal adanya kebijakan ini, karena kurangnya sosialisasi yang dilakukan kepada masyarakat, selain itu karakteristik agen pelaksanan yang kurang aktif dalam mengkomunikasikan kebijakan ini, selain itu dukungan kondisi lingkungan, ekonomi dan politik kurang mendukung, masyarakat cenderung kurangnya kepedulian terhadap adanya pemenuhan hak anak, dan kurangnya dukungan dunia usaha. 


\section{DAFTAR PUSTAKA}

Agustino, L. 2014. Dasar- Dasar Kebijakan Publik. Bandung: Alfabeta.

Mutiarin, D., \& Zaenudin, A. (2014). Manajemen Birokrasi dan Kebijakan. Yogyakarta: Pustaka Belajar.

Peraturan Menteri Negara Pemberdayaan Perempuan dan Perlindungan Anak Nomor 11 Tahun 2011 Tentang Kebijakan Pengembangan Kabupeten/Kota Layak Anak.

Satori, D., \& Komariah, A. (2011). Metodologi Penelitian Kualitatif. Bandung: Alfabeta

Sugiyono. (2014). Metofologi Penelitian Kuantitatif, Kualitatif, dan R\&D. Bandung: Alfabeta

Suharto, E. (2014). Analisi Kebijakan Publik. Bandung: Alfabeta

Tahir, A. (2015). Kebijakan Publik dan Transparansi Penyelenggaraan Pemerintah Daerah. Bandung: Alfabeta.

Undang-Undang Nomor 4 Tahun 2013 Tentang Perlindungan Anak.

Winarno, B. (2014). Kebijakan Publik (Teori, Proses dan Studi Kasus).Yogyakarta: CAPS. 